\title{
Stereoselective Assembly of a 1,3-Diene, via Coupling between an Allenic Acetate and a (B)-Alkylborane: Synthetic Studies on Amphidinolide B1
}

\author{
Amit K. Mandal ${ }^{\dagger}$, John S. Schneekloth Jr. $\ddagger$, and Craig M. Crews ${ }^{\star}, \dagger, \ddagger, \S$ \\ $\dagger$ Department of Molecular, Cellular, and Developmental Biology, Yale University, New Haven, Connecticut \\ 06520-8103 \\ $\$$ Department of Chemistry, Yale University, New Haven, Connecticut 06520-8103 \\ §Department of Pharmacology, Yale University, New Haven, Connecticut 06520-8103
}

\begin{abstract}
The preparation of three fragments for the total synthesis of amphidinolide B1 has been described. The C16 stereochemistry was set by asymmetric allylic alkylation. C21 and C25 stereogenic centers were set by an enantioselective/diastereoselective double allylation reaction. The $\mathrm{C} 9$ configuration was set by an asymmetric heteroene reaction. A differentially substituted stereodefined 1,3-diene iodide was synthesized by iodide-mediated $\mathrm{S}_{\mathrm{N}} 2^{\prime}$ reaction. A novel stereoselective method to assemble a 1,3-diene by coupling an allenic acetate and $(B)$-alkylborane is also reported.
\end{abstract}

Amphidinolide B1 1, a polyketide-based 26-membered macrolide, was isolated from a culture of the symbiotic marine dinoflagellate Amphidinium sp. (strain Y-5) in 1987 by Kobayashi et al. ${ }^{1}$ Compound 1 exhibits potent and selective cytotoxicity against L1210 murine leukemia and $\mathrm{KB}$ human epidermoid carcinoma cell lines in vitro $\left(\mathrm{IC}_{50} 0.00014\right.$ and $0.0042 \mu \mathrm{g} / \mathrm{mL}$, respectively). ${ }^{1,2}$ The relative stereochemistry of the nine stereogenic centers in amphidinolide $\mathrm{B} 1$ was determined by X-ray crystallographic analysis, ${ }^{3}$ and the absolute stereochemistry was assigned on the basis of the chemical synthesis of the C22-C26 segment. ${ }^{4}$ Due to its potent cytotoxic activity and topological complexities, amphidinolide B1 1 has attracted the attention of synthetic chemists for over 15 years. ${ }^{5}$ There have been several efforts toward the total synthesis of this natural product; however, no completed total synthesis has yet been reported. Both Pattenden et al. and Kobayashi et al. reported elegant approaches toward 1.5d,6

Nishiyama, Chakraborty, Myles, Lee, and Carter have also reported partial syntheses toward 1. ${ }^{7}$ In our chemical biology program, we are interested in developing natural products as biological probes to identify novel proteins for therapeutic intervention (target validation) and the exploration of cell biology (chemical genetics). As amphidinolide B1 $\mathbf{1}$ is a highly potent anticancer agent, it can be useful as a tool for understanding more about cancer biology. As a result of our interest in the biology of this molecule, we initiated a program directed toward completing the total synthesis of amphidinolide B1 1.

Our proposed synthetic route to $\mathbf{1}$ is based on a highly convergent disconnection of the 26membered macrolide ring: Mitsunobu-type esterification, ${ }^{8}$ Suzuki-Miyaura coupling 9

craig.crews@yale.edu.

Supporting Information Available: Experimental procedures, characterization data, and stereochemical proofs. This material is available free of charge via the Internet at http://pubs.acs.org. 
between $\mathrm{C} 12$ and $\mathrm{C} 13$, aldol reaction ${ }^{10}$ between $\mathrm{C} 18$ and C19, and Horner-WadsworthEmmons reaction across $\mathrm{C} 2-\mathrm{C} 3$ (Scheme 1).

Use of a 1,3-diene iodide system such as fragment 3 as a substrate for Suzuki-Miyaura coupling is unprecedented in the literature. ${ }^{11}$ We hope to attain a high level of stereo-induction to install the $\mathrm{C} 11$ stereogenic center by proper choice of hydroborating agent and fine-tuning of the protecting groups of the $\mathrm{C} 8$ and $\mathrm{C} 9$ hydroxyl groups to generate the borane from fragment 4 . It is shown that rate of hydroboration is sensitive to electronic as well as steric factors, although steric effects tend to predominate. Electron-rich, unhindered olefins generally react rapidly. It is documented that the 2-propenyl group undergoes hydroboration 600 times faster than a disubstituted internal trans double bond. ${ }^{11 \mathrm{~b}}$ We hope to take advantage of this differential hydroboration rate to preferentially hydroborate the 2-propenyl group, yielding the requisite $(B)$-alkylborane for Suzuki-Miyaura coupling. Though Evans and co-workers reported $\beta$ alkyl-directed diastereoselective hydroboration in an acyclic system, ${ }^{12}$ to the best of our knowledge there is little precedent for $\beta$-alkoxy- or $\beta$-silyloxy-directed successful diastereoselective hydroboration in acyclic systems. ${ }^{13}$ In this letter, we describe the synthesis of fragments $\mathbf{2}, \mathbf{3}$, and $\mathbf{4}$ as well as validation of the 1,3-diene iodide fragment $\mathbf{3}$ as a coupling partner. We also discuss a new stereoselective and regioselective synthesis of a highly substituted 1,3-diene by joining an allenic acetate and an $(B)$-alkylborane in the presence of a palladium catalyst.

The key step in the synthesis of fragment $\mathbf{2}$ is based on the enantioselective/diastereoselective double allylboration reaction to prepare 1,5-syn-diol 8. Adopting Roush's protocol, ${ }^{14}$ we hydroborated allenylboronate 6 using (-)-Ipc ${ }_{2} \mathrm{BH}^{15}$ to produce 1,3-boryl-substituted allylborane 7 .

The allylborane 7 was reacted with benzyloxyacetaldehyde first at $-78{ }^{\circ} \mathrm{C}$ for $2 \mathrm{~h}$, followed by treatment with acetaldehyde at $-78^{\circ} \mathrm{C}$ for $2 \mathrm{~h}$ and at room temperature for $24 \mathrm{~h}$ to produce 1,5-syn-diol 8 in 95\% yield and $\geq 95 \%$ ee based on MTPA ester analysis. Thus, the C21 and epi-C25 hydroxy group (which would be inverted during Mitsunobu esterification) were installed efficiently. We hoped that matched allylic and homoallylic hydroxy-directed epoxidation would afford good selectivity. ${ }^{16}$ However, diastereo-selective epoxidation using $\mathrm{VO}(\mathrm{acac})_{2} / t$-BuOOH gave poor selectivity. Gratifyingly, epoxidation with $m \mathrm{CPBA}$ in $\mathrm{CH}_{2} \mathrm{Cl}_{2}$ furnished epoxy alcohol 9 in an 8:1 diastereoisomeric ratio based on the crude 500 MHz NMR. Bis-silyl protection with TBSOTf/2,6-lutidine was followed by regioselective and stereoselective opening of the epoxide with $\mathrm{Me}_{4} \mathrm{AlLi} / \mathrm{Me}_{3} \mathrm{Al}$ in refluxing hexane. Further silyl protection provided compound 11, which was converted to fragment $\mathbf{2}$ using straightforward functional group manipulations. Stereochemistry at the newly generated hydroxyl-bearing stereocenter was verified by NOE analysis of the acetonide obtained by TBAF deprotection of 10 and subsequent treatment with 2,2-dimethoxypropane (Supporting Information).

The synthesis of fragment 3 began with commercially available racemic isoprene monoxide 12. Palladium- and boron-cocatalyzed dynamic kinetic asymmetric transformation (DYKAT) using $(S, S)$-ligand-13 and $p$-methoxybenzyl alcohol as the nucleophile provided differentially protected alcohol 14 in a highly regio- and enantioselective fashion (90\% yield and $94 \%$ ee). 17 Application of a hydroboration and oxidation sequence furnished the diol. The less sterically hindered of the two primary alcohols was selectively protected as its mono-TBDPS ether to yield alcohol 15. The alcohol 15 was converted to methyl ketone $\mathbf{1 6}$ using common functional group transformations. Chelation-controlled addition of ethynylmagnesium bromide to methyl ketone 16 produced the ethynyl carbinol ( $\mathrm{dr}$ 90:10), which was homologated using $\left(\mathrm{CH}_{2} \mathrm{O}\right)_{n}$ ' $i-\mathrm{Pr}_{2} \mathrm{NH} / \mathrm{CuBr}$ in refluxing dioxane to afford allenic alcohol 17. ${ }^{18}$ Acetylation of $\mathbf{1 7}$ proved to be nontrivial. Powerful acetylation protocols such as $\mathrm{Ac}_{2} \mathrm{O} /$ catalytic TMSOTf $^{19}$ and $\mathrm{Ac}_{2} \mathrm{O} /$ catalytic $\mathrm{Sc}(\mathrm{OTf})_{3}{ }^{20}$ were not successful. However, acetylation was achieved using 
$\mathrm{Ac}_{2} \mathrm{O} / 4$-pyrrolidinopyridine in reproducible, albeit $40-50 \%$ yield. Exposure of the acetate $\mathbf{1 8}$ to acetic acid and lithium iodide exclusively produced $(E)-1,3$-diene iodide fragment $3^{21}$ The olefin geometry was verified by NOE experiments.

We believe that the diastereomeric acetates lead exclusively to the (E)-product by $\mathrm{S}_{\mathrm{N}} 2^{\prime}$ attack of the iodide nucleophile on the central allenic carbon anti to the acetate leaving group on the lowest energy conformation of each diastereomer (B and $\mathbf{D})$. Due to severe 1,3-allylic strain, anti $\mathrm{S}_{\mathrm{N}} 2^{\prime}$ attack of the iodide nucleophile was not favorable on conformations ( $\mathbf{A}$ and $\mathbf{C}$ ), leading to the $(Z)$-isomer. ${ }^{22}$

The synthesis of fragment 4 takes advantage of Evans' $\mathrm{Cu}$ (II)-Box-catalyzed enantioselective heteroene reaction between iso-butene and ethyl glyoxalate 19 to produce homoallylic alcohol 20 in $60 \%$ yield and $93 \%$ ee (Scheme 4 ). ${ }^{23}$ The free alcohol was protected as its corresponding TBS ether and converted to the Weinreb amide 21. In parallel, vinyl iodide $\mathbf{2 3}$ was prepared from commercially available pentyn-1-ol 22 via two steps ${ }^{24}$ in $50 \%$ overall yield. Addition of the vinyl iodide $\mathbf{2 3}$ to the Weinreb amide $\mathbf{2 1}$ smoothly produced $\alpha, \beta$-unsaturated ketone $\mathbf{2 4}$ in $86 \%$ yield. Diastereo-selective reduction using Luche conditions produced an alcohol, which was protected as a TIPS ether to provide fragment 4 . Stereochemical assignment was corroborated on NOE experiment of the corresponding acetonide (Supporting Information).

With all three fragments securely in hand, we next concentrated our efforts on the key SuzukiMiyaura coupling. The viability of fragment $\mathbf{3}$ for use as a coupling partner was demonstrated by its successful coupling with the $(B)$-alkylborane derived from styrene to furnish $\mathbf{2 6}$.

Encouraged by this result, we next investigated the possibility of using allenic acetate $\mathbf{1 8}$ as a coupling partner to a $(B)$-alkylborane. This would increase the efficiency in the context of our present study and also would provide a novel technology to stereoselectively assemble the highly substituted 1,3-diene. We were aware that allenic carbonates can be used to generate vinylpalladium species. ${ }^{25}$ However, to the best of our knowledge, this reaction had not been explored in the context of setting a differentially substituted 1,3-diene. We reasoned that we might be able to generate a vinylpalladium species such as $\mathbf{2 5}$ directly from allenic acetate 18 by treating it with a palladium source and couple it with a $(B)$-alkylborane. We treated allenic acetate 18 with $\left[\mathrm{Pd}(\mathrm{dppf}) \mathrm{Cl}_{2}\right], \mathrm{K}_{3} \mathrm{PO}_{4}, \mathrm{H}_{2} \mathrm{O}$, and the $(B)$-alkylborane derived from styrene and gratifyingly isolated the coupled product 26 in $47 \%$ unoptimized yield. The geometry of the 1,3-diene was confirmed on the basis of NOE experiments. This is the first example of the synthesis of a highly substituted stereodefined 1,3-diene in this fashion. In catalytic reactions, a ( $\pi$-allyl)palladium intermediate can be generated from an allylic carboxylate. ${ }^{26}$ We postulate that a ( $\pi$-allyl)palladium complex 27 is formed by anti oxidative addition on the allenic central carbon. The formed $\pi$-allyl complex 27 presumably then isomerizes to the thermodynamically more stable $(E)$-complex 28 via an $\eta^{3}-\eta^{1}-\eta^{3}$ rearrangement. This isomerization is presumably faster than the product formation because no identifiable ( $Z$ )-isomer was observed. More detailed studies on this coupling will be published in due course.

In conclusion, we have accomplished efficient synthetic routes to all the requisite fragments for amphidinolide B1 1. Our studies document that a $S_{N} 2^{\prime}$ reaction can be used to prepare highly substituted stereodefined 1,3-diene iodide $\mathbf{3}$. We have also demonstrated that an allenic acetate 18 derived ( $\pi$-allyl)palladium species can be coupled with a $(B)$-alkylborane to stereoselectively and regioselectively assemble a 1,3-diene. Our continued investigation into the chemical problems posed by amphidinolide B1 1 and our investigation of its intracellular mode of action will be reported in due course. 


\section{Acknowledgment}

We gratefully acknowledge financial support from NIH (GM062120). J.S.S. acknowledges the American Chemical Society, Division of Medicinal Chemistry, and Aventis Pharmaceuticals for a predoctoral fellowship. We thank Professor John Wood for his help during the preparation of this manuscript.

\section{References}

1. Ishibashi M, Ohizumi Y, Hamashima M, Nakamura H, Hirata Y, Sasaki T, Kobayashi J. J. Chem. Soc., Chem. Commun 1987:1127.

2. Kobayashi J, Ishibashi M, Nakamura H, Ohizumi Y, Yamasu T, Hirata Y, Sasaki T, Ohta T, Nozoe S. J. Nat. Prod 1989;52:1036. [PubMed: 2607346]

3. Bauer I, Maranda L, Shimizu Y, Peterson RW, Cornell L, Steiner JR, Clardy J. J. Am. Chem. Soc 1994;116:2657.

4. Ishibashi M, Ishiyama H, Kobayashi J. Tetrahedron Lett 1994;35:8241.

5. (a) Kobayashi J, Ishibashi M. Chem. Rev 1993;93:1753. (b) Chakraborty T, Das S. Curr. Med. Chem.: Anti-Cancer Agents 2001;1:131. (c) Kobayashi J, Shimbo K, Kubota T, Tsuda M. Pure Appl. Chem 2003;75:337. (d) Kobayashi J, Tsuda M. Nat. Prod. Rep 2004;21:77. [PubMed: 15039836]

6. (a) Cid MB, Pattenden G. Synlett 1998:540. (b) Cid MB, Pattenden G. Tetrahedron Lett 2000;41:7373. (c) Ishiyama H, Takemura T, Tsuda M, Kobayashi J. Tetrahedron 1999;55:4583. (d) Ishiyama H, Takemura T, Tsuda M, Kobayashi J. J. Chem. Soc., Perkin Trans. 1 1999:1163.

7. (a) Ohi K, Shima K, Hamada K, Saito Y, Yamada N, Ohba S, Nishiyama S. Bull. Chem. Soc. Jpn 1998;71:2433. (b) Ohi K, Nishiyama S. Synlett 1999:573. (c) Ohi K, Nishiyama S. Synlett 1999:571. (d) Chakraborty TK, Thippeswamy D, Suresh VR, Jayaprakash S. Chem. Lett 1997:563. (e) Chakraborty TK, Thippeswamy D. Synlett 1999:150. (f) Chakraborty TK, Thippeswamy D, Jayaprakash S. J. Ind. Chem. Soc 1998;75:741. (g) Chakraborty TK, Suresh VR, Vayalakkada R. Chem. Lett 1997:565. (h) Eng HM, Myles DC. Tetrahedron Lett 1999;40:2275. (i) Eng HM, Myles DC. Tetrahedron Lett 1999;40:2279. (j) Lee D-H, Lee S-W. Tetrahedron Lett 1997;38:7909. (k) Lee D-H, Rho M-D. Bull. Korean Chem. Soc 1998;19:386. (1) Lee D-H, Rho M-D. Tetrahedron Lett 2000;41:2573. (m) Zhang W, Carter RG, Yokochi AFT. J. Org. Chem 2004;69:2569. [PubMed: 15049660]

8. Mitsunobu O. Synthesis 1981:1.

9. Miyaura N, Ishiyama T, Sasaki H, Ishikawa M, Satoh M, Suzuki A. J. Am. Chem. Soc 1989;111:314.

10. Evans DA, Carter PH, Carreira EM, Charette AB, Prunet JA, Lautens M. J. Am. Chem. Soc 1999;121:7540.

11. (a) Miyaura M, Suzuki A. Chem. Rev 1995;95:2457. (b) Chemler SR, Trauner D, Danishefsky SJ. Angew. Chem., Int. Ed 2001;40:4544.

12. Evans DA, Bartroli J, Godel T. Tetrahedron Lett 1982;23:4577.

13. Morimoto Y, Mikami A, Kuwabe S-i, Shirahama H. Tetrahedron Lett 1991;32:2909.

14. Flamme EM, Roush WR. J. Am. Chem. Soc 2002;124:13644. [PubMed: 12431072]

15. Brown HC, Singaram B. J. Org. Chem 1984;49:945.

16. Hoveyda AH, Evans DA, Fu GC. Chem. Rev 1993;93:1370.

17. Trost BM, McEachern EJ, Toste FD. J. Am. Chem. Soc 1998;120:12702.

18. Searles S, Li Y, Nassim B, Lopes M-TR, Tran PT, Crabbé P. J. Chem. Soc., Perkin Trans. 1 1984:747. 19. Procopiou PA, Baugh SPD, Flack SS, Inglis GGA. J. Org. Chem 1998;63:2342.

20. Ishihara K, Kubota M, Kurihara H, Yamamoto H. J. Am. Chem. Soc 1995;117:4413.

21. Horváth A, Bäckvall J-E. J. Org. Chem 2001;66:8120. [PubMed: 11722214]

22 . This hypothesis is supported by our observation that the $(E)$-selectivity diminishes slightly as the bulk of $\mathrm{R}_{\mathrm{L}}$ decreases (unpublished results).

23. Evans DA, Tregay SW, Burgey CS, Paras NA, Vojkovsky T. J. Am. Chem. Soc 2000:7936.

24. Reich HJ, Eisenhart EK, Olson RE, Kelly MJ. J. Am. Chem. Soc 1986;108:7791.

25. Moriya T, Furuuchi T, Miyaura N, Suzuki A. Tetrahedron 1994;50:7961.

26. (a) Trost BM. Acc. Chem. Res 1980;13:385.Godleski, SA. Chapter 3.3. In: Trost, BM.; Fleming, I.; Shammelhack, MF., editors. Comprehensive Organic Synthesis. Vol. 4. Oxford: Pergamon; 1991. 


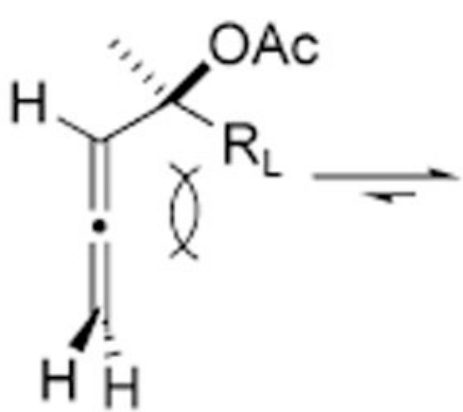

A
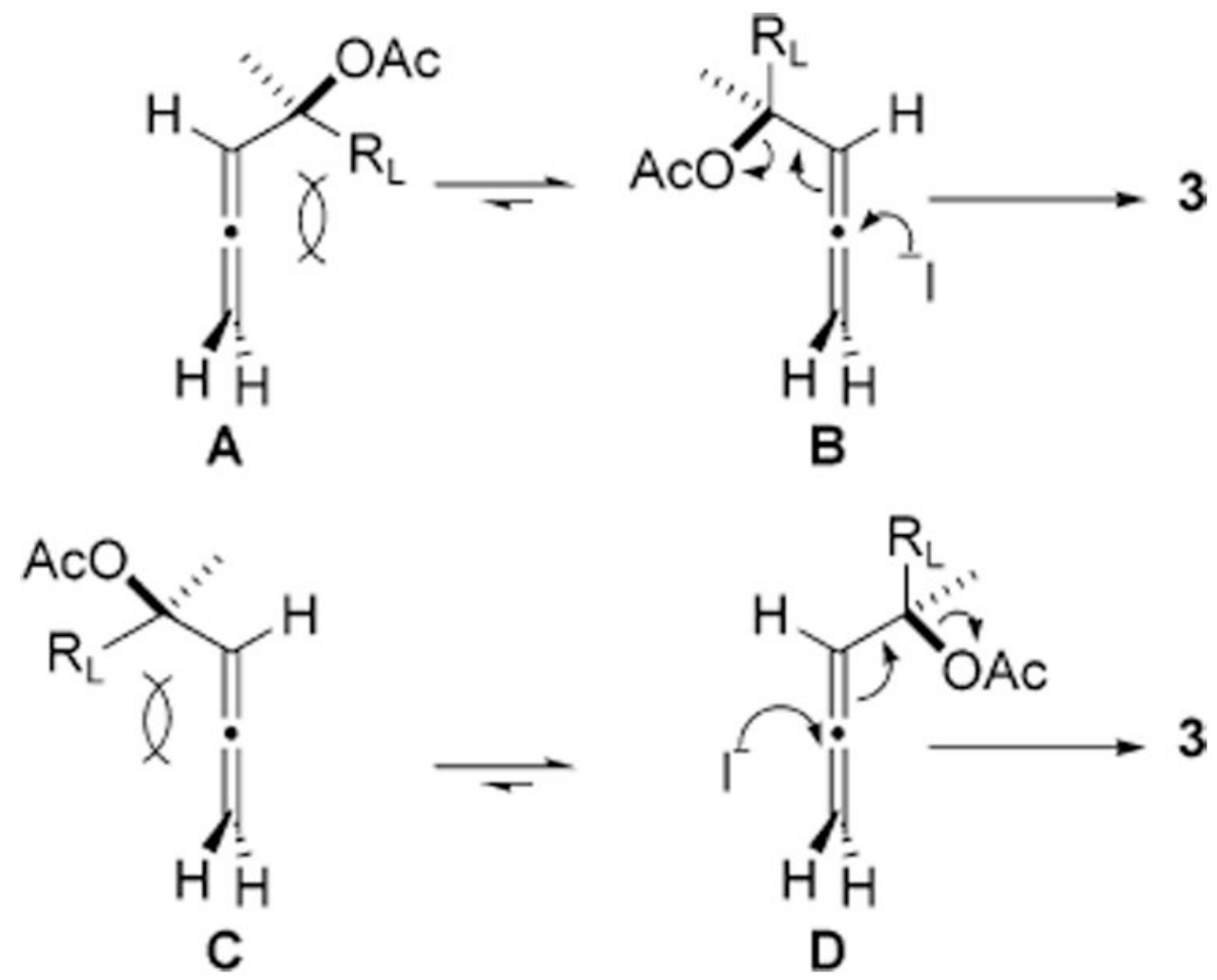

Figure 1.

Stereochemical rationale for $\mathrm{S}_{\mathrm{N}} 2^{\prime}$ reaction. 


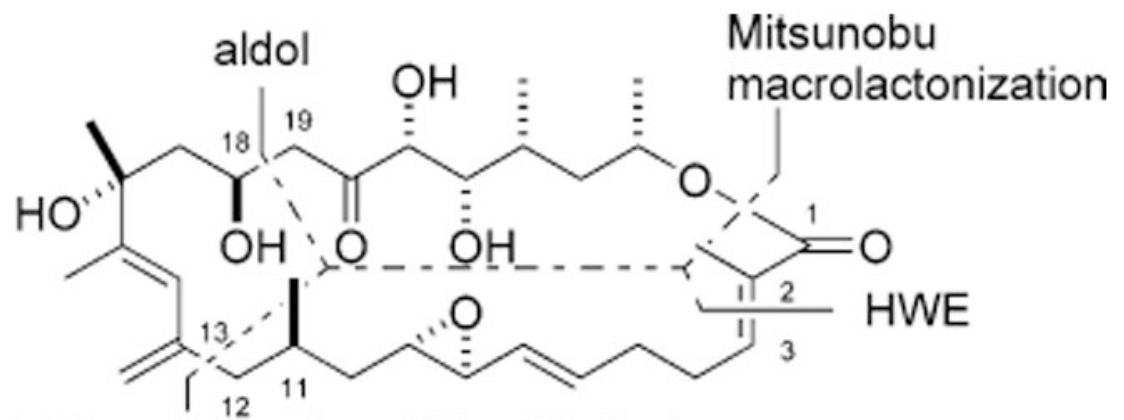

Suzuki-Miyaura Amphidinolide B 1 coupling

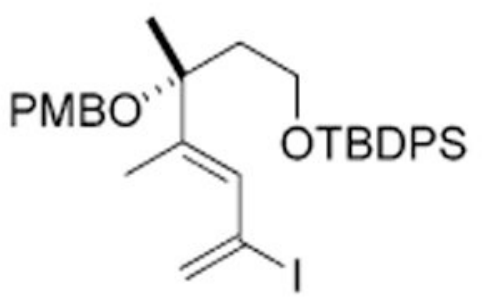

Fragment 3

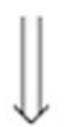<smiles>CC(=O)[C@H](O[SbH3])[C@@H]([OH+])[C@@H](C)CC(C)[OH2+]</smiles>

Fragment 2<smiles>CCOP(=O)(OCC)C(C)C(=O)O</smiles>

Fragment 4

5

Scheme 1.

Retrosynthetic Analysis 
<smiles>O=C(C=CC=CB1OC(c2ccccc2)(c2ccccc2)C(c2ccccc2)(c2ccccc2)O1)CCCl</smiles><smiles>FC(F)(F)[I-](C/C=C/B1OC(c2ccccc2)(c2ccccc2)C(c2ccccc2)(c2ccccc2)O1)C(F)(F)F</smiles>

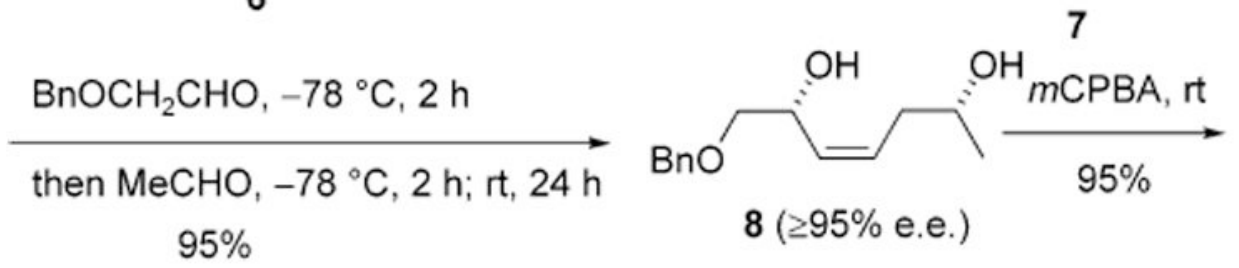

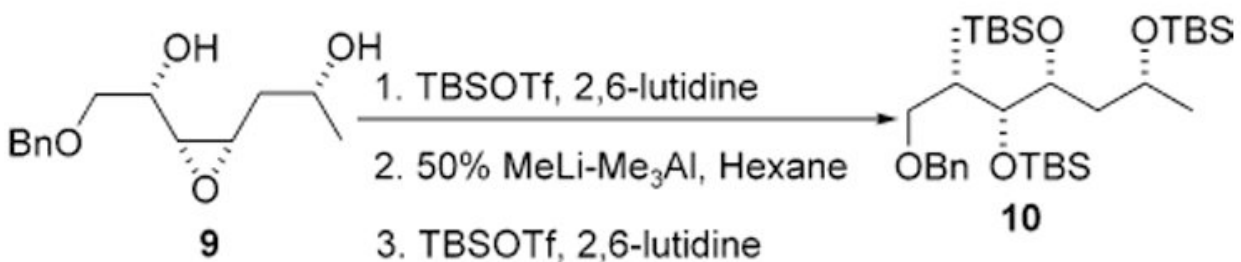
$86 \%$

1. $\mathrm{Pd}(\mathrm{OH})_{2}, \mathrm{H}_{2}, \mathrm{MeOH}, 0.5 \mathrm{~h}$

2. DMP, $\mathrm{CH}_{2} \mathrm{Cl}_{2}, \mathrm{rt}, 45 \mathrm{~min}$

3. $\mathrm{MeMgBr}, \mathrm{THF},-78^{\circ} \mathrm{C}, 1.5 \mathrm{~h}$

4. DMP, $\mathrm{CH}_{2} \mathrm{Cl}_{2}, \mathrm{rt}, 30 \mathrm{~min}$ $60 \%$

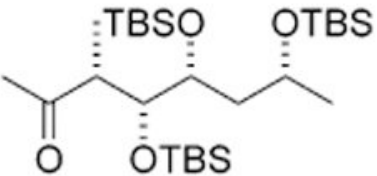

Fragment 2

Scheme 2.

Synthesis of Fragment 2 

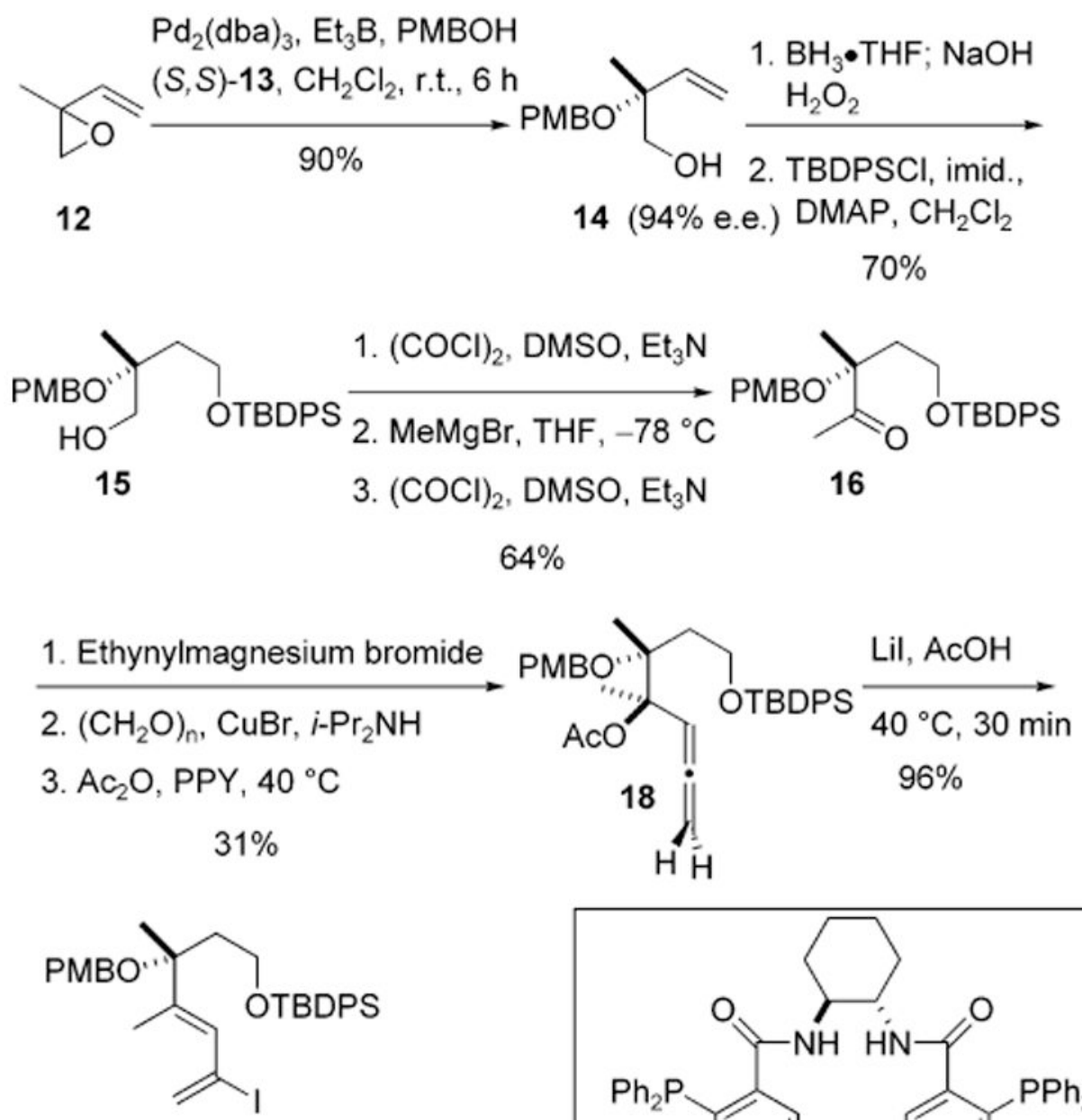

Fragment 3

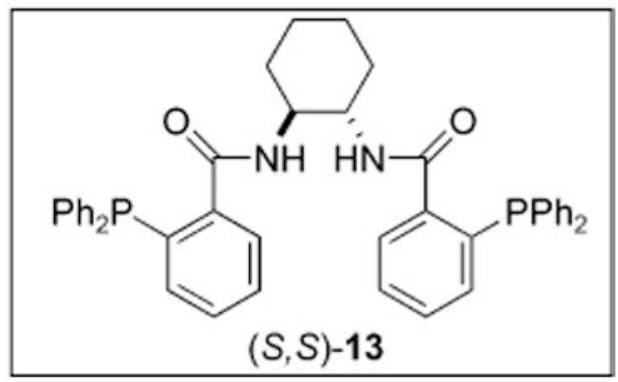

Scheme 3.

Synthesis of Fragment $\mathbf{3}$ 


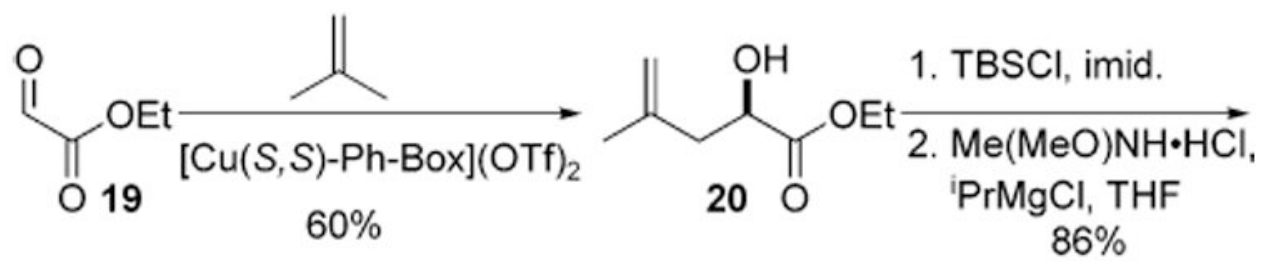<smiles>C=C(C)CC([Se-])C(=O)N(C)OC</smiles><smiles>C=C(C)CC([OH+])C(=O)/C=C/CCCOC(C)(C)C</smiles>

\begin{tabular}{l|r}
$\mathrm{PMBCl}, \mathrm{NaH}$ & $70 \%$ \\
$n-\mathrm{Bu}_{4} \mathrm{NI}, \mathrm{THF}$ & $\mathrm{OH}$
\end{tabular}

\section{4}

$77 \%$ 1. $\mathrm{CeCl}_{3}, \mathrm{NaBH}_{4}, \mathrm{MeOH}$<smiles>OCCC/C=C/I</smiles>

22

2. TIPSOTf, 2,6-lutidine<smiles>C=C(C)CC([OH+])C(/C=C/CCCOC(C)(C)C)[OH+]C(F)(F)F</smiles>

Fragment 4

Scheme 4.

Synthesis of Fragment 4 


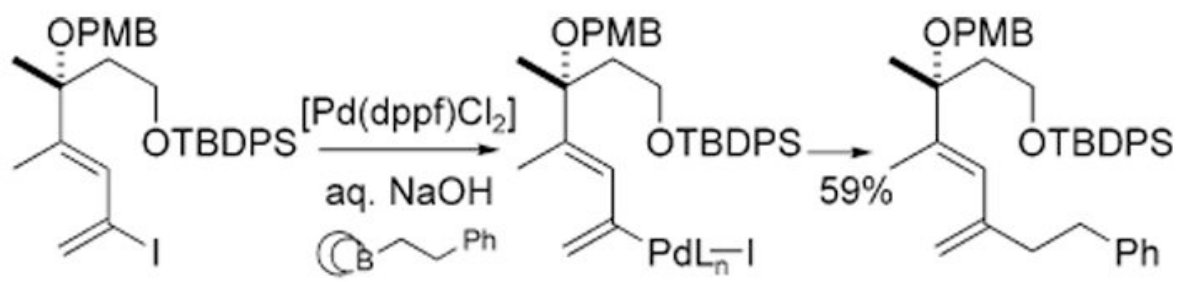

Fragment 3

25

26

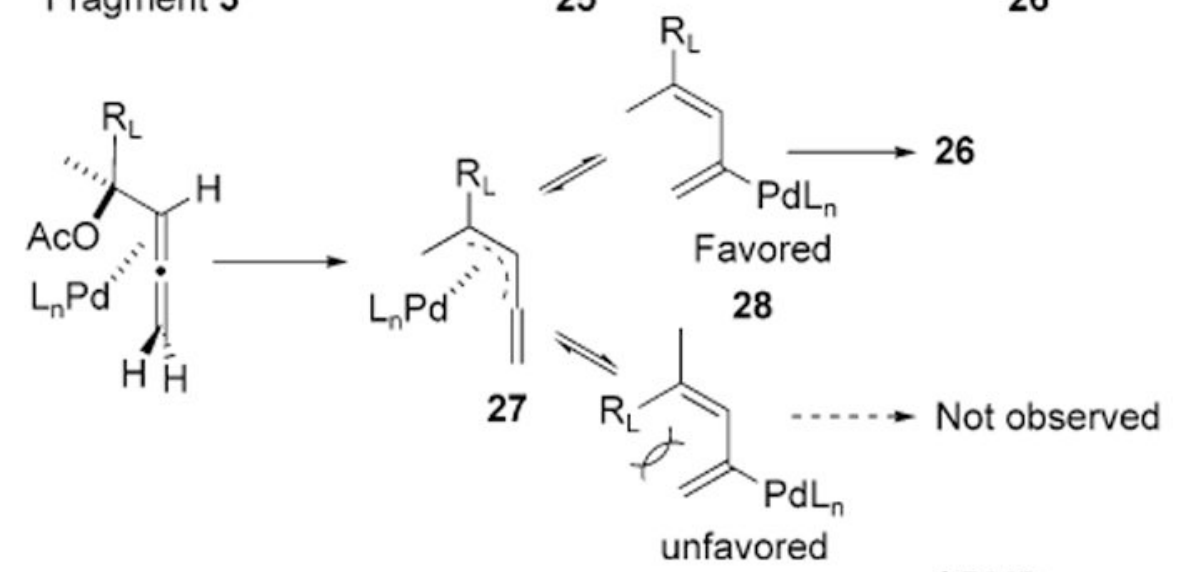

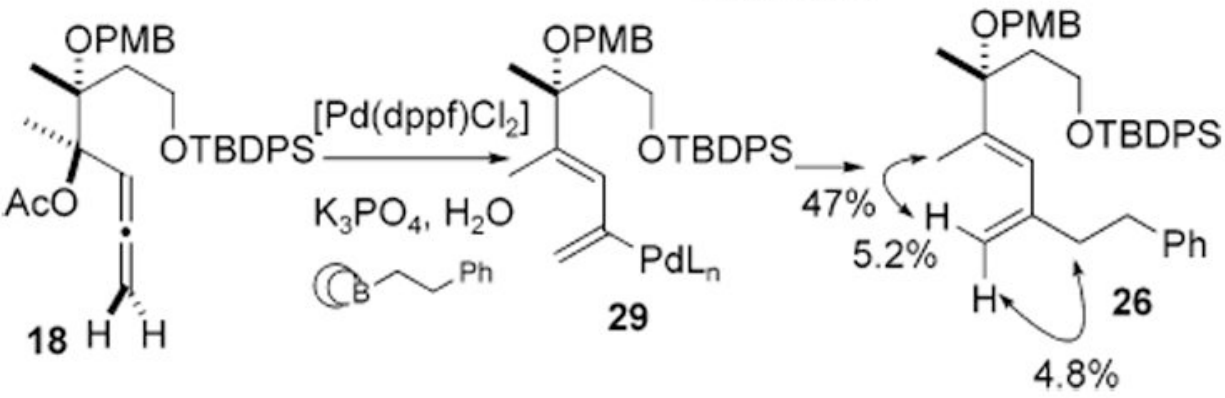

Scheme 5.

Stereoselective Synthesis of Stereodefined 1,3-Diene 